\title{
Exploring the Impacts of Labor Migration and Job Satisfaction on Organizational Commitment of Foreign Workers in Taiwan's Construction Industry: Employ Ability as a Moderator
}

\author{
Pei-Wen Liao \\ Department of Public Management and Policy, Tunghai University, Tunghai City, Taiwan \\ Email: pearlliao@thu.edu.tw
}

Received 11 February 2015; accepted 23 March 2015; published 27 March 2015

Copyright (C) 2015 by author and Scientific Research Publishing Inc.

This work is licensed under the Creative Commons Attribution International License (CC BY). http://creativecommons.org/licenses/by/4.0/

(c) (i) Open Access

\begin{abstract}
The purpose of this study is to understand employability into the moderator through which labor migration and job satisfaction are related to organizational commitment. A survey study was conducted on 440 Thai workers from construction industry in Taiwan. Using structural equation modeling (SEM), our analysis indicates that labor migration is significantly related to their feelings of satisfaction to the organizational commitment. After analyzing the survey questionnaires, we find the positive relationship among push migration, pull migration, interpersonal satisfaction, salary satisfaction, and organizational commitment. Furthermore, the result shows the positive significant moderating effects of employability on push migration and job satisfaction. However, the push migration has a significantly positive effect on job satisfaction in lower employability of foreign workers.
\end{abstract}

\section{Keywords}

Employability, Labor Migration, Job Satisfaction, Organizational Commitment

\section{Introduction}

With globalization on the rise, there are more and more companies employing foreign workers. At the same time, to cope with the increase in production costs, employers adopted many new HR strategies, such as taking on 
lower wage foreign workers with the permission of the government, and improving the efficiency of the workforce by providing more training, introducing automated machinery to substitute for labor and subcontracting their work [1]. As Taiwan entered into a new stage of globalization and became more deeply incorporated into the global capitalist system in the 1980s, foreign workers steadily became a conspicuous presence in the country [2]. These guidelines are provided by the Bureau of Employment and Vocational Training (BEVT) of foreign workers of surveyed in Taiwan between years 2011 and 2012.

At present, it is reported that there are some 441,507 foreign workers in Taiwan, the majority of which come from Southeast Asia. These processes of environmental change may act as one of many labors outmigrations from a region. Human efforts to maintain current environmental states may likewise function as push or pull factors in transnational labor migration through either curtailing or generating job opportunities [3]. According to DeSantis referred many scholars and governmental agencies have attempted to explain that phenomenon known as the laws of migration term to the Push-Pull Theory [4].

Based on Ahmed and Rafiq conveyed the high satisfactions of employee are positively related to higher organizational commitment [5]. The human resources approach is one of the factors of success that in satisfied of organizations is going to have high motivated employees [6]. The purpose of these activities would be increasing the job quality of employee [7]. A number of empirical studies confirmed the important role of job satisfaction and organizational commitment [8] [9]. This research explored the migration theory of push migration and pull migration on the relationships among relationship satisfaction, salary satisfaction, and organizational commitment. Furthermore, the employability moderates both the relationship between labor migration and satisfaction and the relationship between satisfaction and organizational commitment.

\section{Literature Review}

There is evidence suggesting that labor migration has become a major strategy for many governments around the globe. According to Tynaliev and McLean [10] several migration theories exist, among which are such theories as migration systems theory, new economics of labor migration theory, and neoclassical economics theory with its treatment of migration. The push-pull component of the PPM model of migration has a long history, dating back to the nineteenth century. These processes of environmental change may act as one of many drivers of labor outmigration from a region. Human efforts to maintain current environmental states may likewise function as push or pull factors in transnational labor migration through either curtailing or generating job opportunities [3]. Early on 1998 by DeSantis referred the scholars and governmental agencies have attempted to explain this phenomenon known as "The Great Migration” according to the Push-Pull Theory [4].

Therefore, this study wanted to understand, foreign workers in Taiwan of push-pull migration factors working for the impact of the job satisfaction. Moreover, understanding the relationship between the job satisfaction and organizational commitment can help foreign workers provide feedback and make managers more effective. Organizational commitment as proven to be the most important commitment in terms of its influence on work performance and on workers' desire to remain in the organization [11]. The employability is a predisposition toward being employed [12]. The objective definition of employability focuses on being reemployed and relates to the experience and specific job skills of the person [13] [14]. Fugate et al. [12] model includes three core person-centered dimensions that make up the employability construct: career identity, personal adaptability, and social and human capital. These dimensions can operate separately. Thus, this research focuses on employability moderates the relationship between labor migration motivation and job satisfaction; and the employability moderates the relationship between job satisfaction and organizational commitment. A number of empirical studies confirm the important role of job satisfaction and organizational commitment in the turnover process [15]-[17]. This study attempts to distinguish between high and low employ ability to understand the relationship among labor migration motivation, job satisfaction and organizational commitment. The following hypotheses are proposed:

H1a. Push migration motivation has a positive effect on interpersonal satisfaction.

H1b. Push migration motivation has a positive effect on salary satisfaction.

H2a. Pull migration motivation has a positive effect on interpersonal satisfaction.

H2b. Pull migration motivation has a positive effect on salary satisfaction.

H3a. Interpersonal satisfaction has a positive effect on organizational commitment.

H3b. Salary satisfaction has a positive influence on organizational commitment. 
H4. Employability moderates the relationship between labor migration motivation (push and pull migration) and satisfaction (interpersonal and salary satisfaction).

H5. Employability moderates the relationship between satisfaction (interpersonal and salary satisfaction) and organizational commitment.

\section{Research Methodology}

In summary, our exploration of the extant literature to identify the relationships between Labor migration, Satisfaction and organizational commitment has considered both a direct and indirect relationship between input factors and outcomes. In order to explore these relationships further, we present these in a model in Figure 1.

\subsection{Data Collection}

To test the hypotheses, International Manpower Agency Company in the Taiwan was surveyed in 2009. For the purpose of corporate anonymity, the organizations are referred to here as Concrete, Building industry, representing the sectors to which they belong. In total, 440 Thai workers were received from the Manpower Agency Company.

\subsection{Measures}

There are six variables were included regarding the push migration, pull migration, interpersonal satisfaction, salary satisfaction, organizational commitment and employability as experienced by Thai workers. First, the labor migration based on work by [18] [19], the measure for push and pull migration for Thai workers. Two dimensions of distributive justice emerged in the factor analysis push migration (Cronbacha $\alpha=0.70$ ) and pull migration (Cronbacha $\alpha=0.71$ ). Second, the measurement of Satisfaction by Chen [20] was based on two dimensions of interpersonal satisfaction (Cronbacha $\alpha=0.77$ ) and salary satisfaction (Cronbacha $\alpha=0.84$ ). The list consist total of 4 items using 5-Likert scales from 1 "not at all", to 5 "very highly". Third scales measures organizational commitment by McMurray, Scott and Pace [21] contract with four items Cronbacha $\alpha$ of 0.814 , asking the respondents to what extent they feel their employer has fulfilled his/her obligations on a five point scale from 1 "not at all" to 5 "very highly". The last scale measures employability based by Department of Labor [22], the measure for employability in Thai workers asked their ability confirm equity and integrity. Three items were included. The employability in Thailand foreign works scale had a Cronbach $\alpha$ of 0.75 .

The confirmatory factor analysis suggested six underlying factors for our model $\chi^{2}=410.52, \mathrm{df}=137$, GFI $=$ 0.91). The results of these analyses are shown in Table 1 . The results indicated that factor loadings of the research constructs ranged from 0.61 to 0.81 and composite reliability ranged from 0.72 to 0.84 . Average variance extracted ranged from 0.46 to 0.57 . Therefore, the measurement scales for each construct were found to be reliable and valid.

\section{Results}

Standardized path coefficients in the hypothesized model are shown in Figure 2. As expected, H1a, H2ab, and

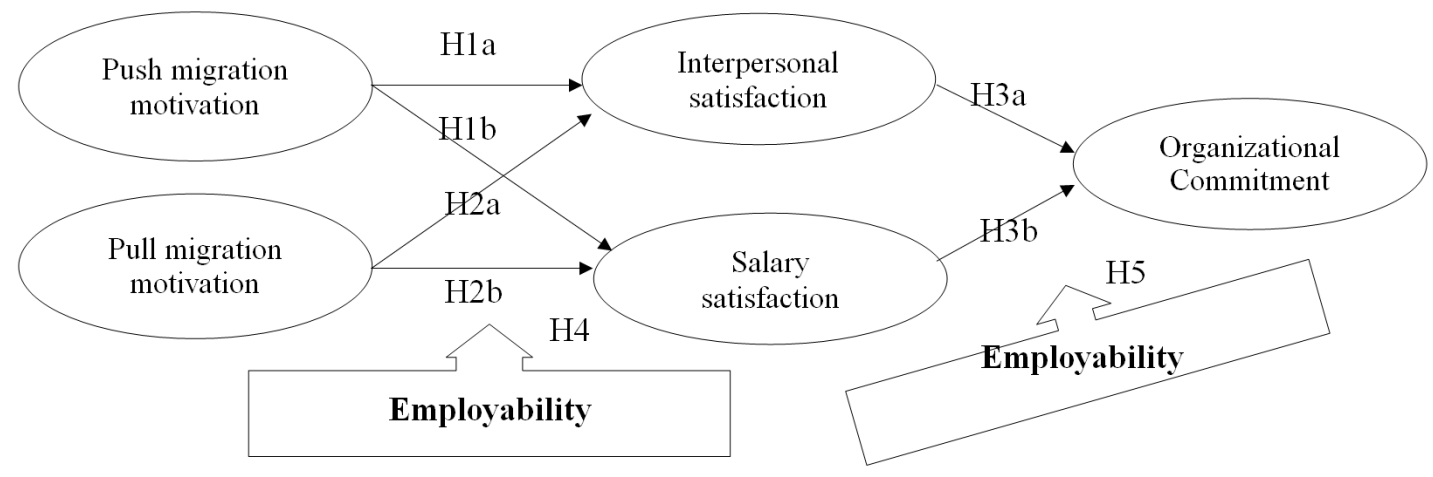

Figure 1. Research model. 


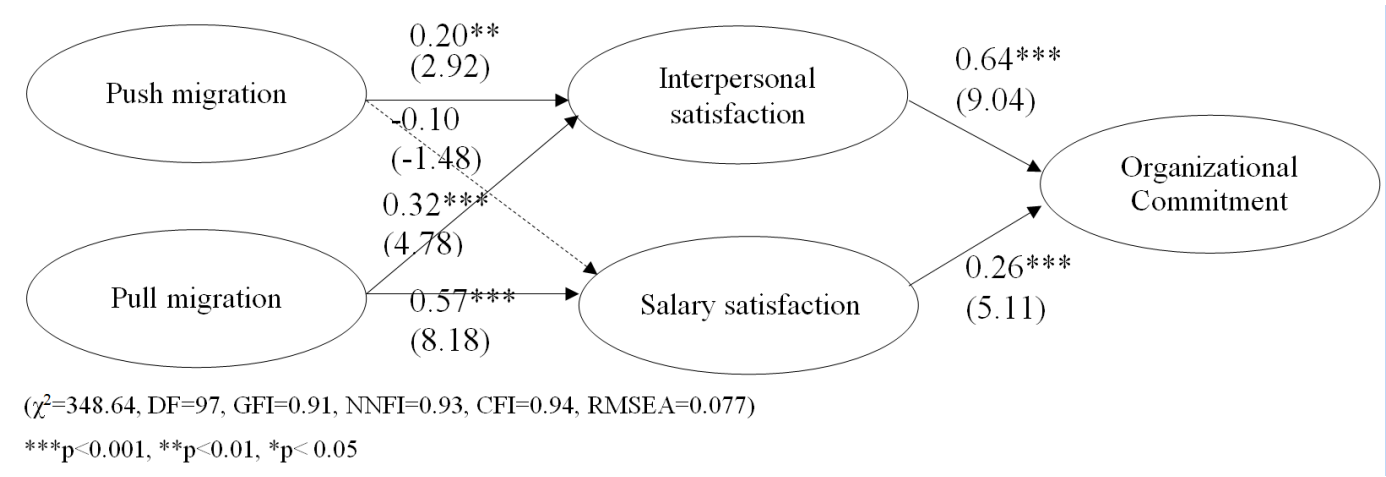

Figure 2. Full model.

Table 1. Factor alysis and reliability tests.

\begin{tabular}{|c|c|c|c|c|}
\hline Variable & Item & $\lambda$ & CR & AVE \\
\hline Push migration & $\begin{array}{l}\text { 1) Socioeconomic environment failed in my country. } \\
\text { 2) Unemployment increase in my country. }\end{array}$ & $\begin{array}{l}0.74 \\
0.71\end{array}$ & 0.67 & 0.52 \\
\hline Pull migration & $\begin{array}{l}\text { 1) Salary items in Taiwan more than other countries. } \\
\text { 2) Consumer prices in Taiwan has lower compared with other countries. } \\
\text { 3) Economic development and social living environment in Taiwan has better. }\end{array}$ & $\begin{array}{l}0.63 \\
0.65 \\
0.75\end{array}$ & 0.72 & 0.46 \\
\hline $\begin{array}{l}\text { Interpersonal } \\
\text { satisfaction }\end{array}$ & $\begin{array}{l}\text { 1) Satisfaction of working partners. } \\
\text { 2) Satisfaction of working partners } \\
\text { 3) Satisfaction of leader and manager. }\end{array}$ & $\begin{array}{l}0.72 \\
0.81 \\
0.66\end{array}$ & 0.78 & 0.54 \\
\hline Salary satisfaction & $\begin{array}{l}\text { 1) Satisfaction of working salary. } \\
\text { 2) Satisfaction of working bonus. } \\
\text { 3) Satisfaction of working guaranteed. } \\
\text { 4) Satisfaction of working environment. }\end{array}$ & $\begin{array}{l}0.73 \\
0.73 \\
0.77 \\
0.78\end{array}$ & 0.84 & 0.57 \\
\hline $\begin{array}{l}\text { Organizational } \\
\text { commitment }\end{array}$ & $\begin{array}{l}\text { 1) The related to my work that is the most important. } \\
\text { 2) I feel honor in this company working. } \\
\text { 3) I am willing to do extra work to help company. } \\
\text { 4) I accept all kind of work tasks to continue for working in this company. }\end{array}$ & $\begin{array}{l}0.62 \\
0.74 \\
0.75 \\
0.78\end{array}$ & 0.82 & 0.53 \\
\hline Employability & $\begin{array}{l}\text { 1) I can perform the job content more effectively. } \\
\text { 2) I can implement the job of specific technical skills and occupational knowledge. } \\
\text { 3) My ability to fit into this job contents setting. }\end{array}$ & $\begin{array}{l}0.73 \\
0.84 \\
0.61\end{array}$ & 0.77 & 0.53 \\
\hline
\end{tabular}

H3ab were supported. The central routes of push migration contents had a significant and positive impact on interpersonal satisfaction $(\beta=0.20, \mathrm{p}<0.05)$. Moreover, pull migration have a significant impact on interpersonal satisfaction $(\beta=0.32, \mathrm{p}<0.05)$ and significant impact on salary satisfaction $(\beta=0.57, \mathrm{p}<0.05)$. However, peripheral routes for interpersonal satisfaction have a significant impact on organizational commitment $(\beta=0.64$, $\mathrm{p}$ $<0.05)$. And salary satisfaction have a significant impact on organizational commitment $(\beta=0.26, \mathrm{p}<0.05)$. The push migration, pull migration, interpersonal satisfaction, salary satisfaction, and organizational commitment are relationship: Using path analysis and the parameters of the significant path coefficient. The employ ability is the mediation effects of migration, satisfaction and organizational commitment.

Researcher continued to explore the employability differences. As indicated in Figure 3, the push migration positively affects interpersonal satisfaction for lower employability group $(\beta=0.3, \mathrm{p}<0.05)$. The pull migration has positive effect of interpersonal satisfaction $(\beta=0.35, \mathrm{p}<0.01)$ and salary satisfaction $(\beta=0.52, \mathrm{p}<0.01)$. There is significant relationship between interpersonal satisfaction and organizational commitment $(\beta=0.52$, $\mathrm{p}$ $<0.01)$. Moreover, there is a significant relationship between salary satisfaction and organizational commitment $(\beta=0.22, \mathrm{p}<0.05)$ for the model were all significant for the lower employability group.

On the other hand, for the higher employability group, the path coefficients for the pull migration positively affects interpersonal satisfaction $(\beta=0.25, \mathrm{p}<0.05)$ and salary satisfaction $(\beta=0.64, \mathrm{p}<0.01)$. The interpersonal satisfaction has a positive influence on organizational commitment $(\beta=0.64, \mathrm{p}<0.01)$. The satisfaction also has a positive influence on organizational commitment $(\beta=0.33, \mathrm{p}<0.01)$ links in the model were all 


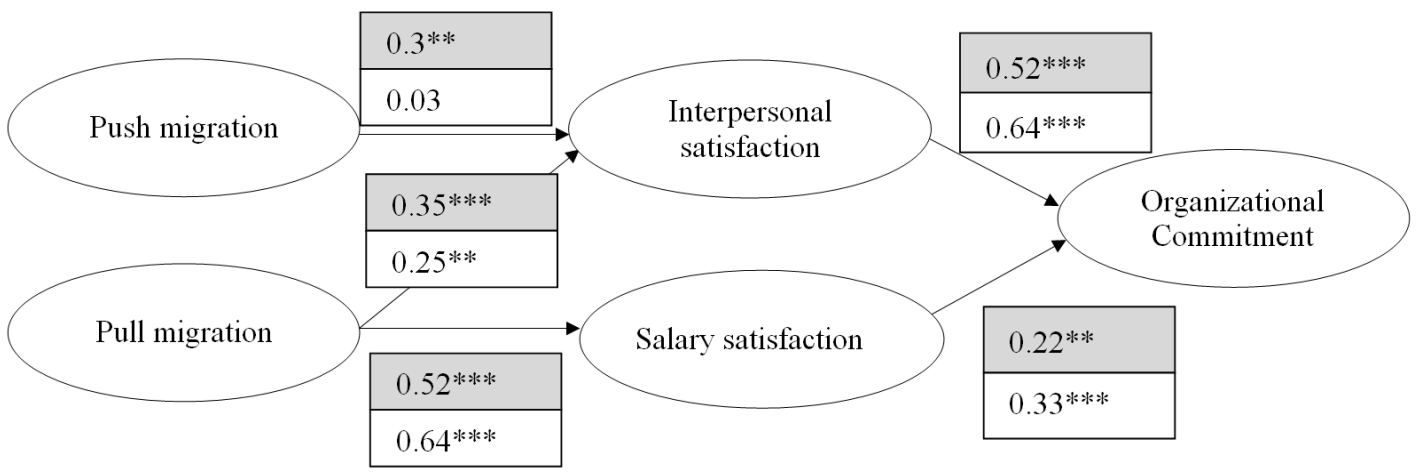

Coefficients for lower employability groups are in the shaded boxes $(n=168)$

$* * * \mathrm{p}<0.001, * * \mathrm{p}<0.01, * \mathrm{p}<0.05$

Figure 3. Path coefficients for lower and higher employability groups.

significant. However, the effect of push migration on interpersonal satisfaction was not significant for the higher employability groups.

\section{Conclusion}

The result that the relationships of the labor migration motivation on job satisfaction, and organizational commitment are positive and significant is consistent with previous findings. The result shows that the relationship between pull migration motivation and job satisfaction is in line with the findings of previous studies [23]. This result indicates that those who are more pull migration motivated with their jobs include, interpersonal and salary are more satisfied to their organizations. However, the relationship between push migration motivation and interpersonal satisfaction is in line with the findings. This result indicates that those who are more pull migration motivated with their jobs include, interpersonal and salary are more satisfied to their organizations. The result that the relationship between job satisfaction and organizational commitment is positive and significant is in line with the findings of previous studies [16] [17]. This result indicates that those who are more interpersonal and salary satisfied with their jobs are more committed to their organizations.

On the other hand, the present study contributes to the extant literature in general, human resource management and sociology literature in particular by employability as a moderator of the effects of migration motivation on job satisfaction via data gathered from the Manpower Agency Company. Results demonstrate that the effect of push migration motivation on interpersonal satisfaction is strong among Thai workers with lower employability. Thai workers low in employability can cope with problems emanating from difficulties between local environment and unemployment. They are likely to have high interpersonal satisfaction in Taiwan. Therefore, the results reported in this study provide additional insights regarding employability as a moderator of the effects of push migration motivation on interpersonal satisfaction.

\section{References}

[1] Lee, J.S. (1995) Economic Development and the Evolution of Industrial Relations in Taiwan, 1950-1993 in Employment Relations in the Growing Asian Economies. In: Verma, A., Kochan, T.A. and Lansbury, R.D., Eds., Routledge, London.

[2] Hwang, J.T., Wang, C.H. and Chung, C.P. (2011) Is It Possible to Decouple Foreign Workers' Wages from the Minimum Wage in Taiwan? The Economic and Labour Relations Review, 22, 107-130. http://dx.doi.org/10.1177/103530461102200206

[3] Radel, C., Schmook, B. and McCandless, S. (2010) Environment, Transnational Labor Migration, and Gender: Case Studies from Southern Yucatán, Mexico and Vermont, USA. Population and Environment, 32, 177-197. http://dx.doi.org/10.1007/s11111-010-0124-y

[4] DeSantis, A.D. (1998) Selling the American Dream Myth to Black Southerners: The Chicago Defender and the Great Migration of 1915-1919. Western Journal of Communication, 62, 474-511. http://dx.doi.org/10.1080/10570319809374621 
[5] Ahmed, P.K. and Rafiq, M. (2003) Internal Marketing Issues and Challenges. European Journal of Marketing, 37, 1177-1186. http://dx.doi.org/10.1108/03090560310498813

[6] Lings, I.N. (2000) The Impact of Internal Market Orientation on External Market Orientation and Business Performance: An Empirical Study of the U.K. Retail Market, ANZMAC Visionary Marketing for the 21st Century: Facing the Challenge.

[7] Ballantyne, D. (2000) The Strengths and Weaknesses of Internal Marketing. In: Varey, R.J. and Lewis, B.R., Eds., Internal Marketing: Directions for Management, Routledge, London. http://dx.doi.org/10.4324/9780203207352.ch3

[8] Silverthorne, C. (2004) The Impact of Organizational Culture and Person-Organization Fit on Organizational Commitment and Job Satisfaction in Taiwan. Leadership \& Organization Development Journal, 25, 592-599. http://dx.doi.org/10.1108/01437730410561477

[9] Nele, D.C. and Hans, D.W. (2006) Autonomy and Workload among Temporary Workers: Their Effects on Job Satisfaction, Organizational Commitment, Life Satisfaction, and Self-Rated Performance. International Journal of Stress Management, 13, 441-459. http://dx.doi.org/10.1037/1072-5245.13.4.441

[10] Tynaliev, U.M. and McLean, G.N. (2011) Labour Migration and National Human Resource Development in the Context of Post-Soviet Kyrgyzstan. Human Resource Development International, 14, 199-215. http://dx.doi.org/10.1080/13678868.2011.558316

[11] Freund, A. (2005) Commitment and Job Satisfaction as Predictors’ Turnover Intentions among Welfare Workers. Administration in Social Work, 29, 5-21. http://dx.doi.org/10.1300/J147v29n02_02

[12] Fugate, M., Kinicki, A.J. and Ashforth, B.E. (2004) Employability: A Psycho-Social Construct, Its Dimensions, and Applications. Journal of Vocational Behavior, 65, 14-38. http://dx.doi.org/10.1016/j.jvb.2003.10.005

[13] Finn, D. (2000) From Full Employment to Employability: A New Deal for Britain’s Unemployed? International Journal of Manpower, 21, 384-399. http://dx.doi.org/10.1108/01437720010377693

[14] Van der Heijden, B. (2002) Prerequisites to Guarantee Life-Long Employability. Personnel Review, 31, 44-61. http://dx.doi.org/10.1108/00483480210412418

[15] Chen, Z.X. and Francesco, A.M. (2003) The Relationship between the Three Components of Commitment and Employee Performance in China. Journal of Vocational Behavior, 62, 490-510. http://dx.doi.org/10.1016/S0001-8791(02)00064-7

[16] Hayati, K. and Caniago, I. (2012) Islamic Work Ethic: The Role of Intrinsic Motivation, Job Satisfaction, Organizational Commitment and Job Performance. Procedia-Social and Behavioral Sciences, 65, 1102-1106. http://dx.doi.org/10.1016/j.sbspro.2012.11.122

[17] Yeh, Y.P. (2014) Exploring the Impacts of Employee Advocacy on Job Satisfaction and Organizational Commitment: Case of Taiwanese. Journal of Air Transport Management, 36, 94-100. http://dx.doi.org/10.1016/j.jairtraman.2014.01.002

[18] Anjomani, A. (2002) Regional Growth and Interstate Migration. Socio-Economic Planning Sciences, 36, 239-265. http://dx.doi.org/10.1016/S0038-0121(02)00010-1

[19] Zhang, K.H. and Song, S. (2003) Rural-Urban Migration and Urbanization in China: Evidence from Time-Series and Cross-Section Analyses. China Economic Review, 14, 386-400. http://dx.doi.org/10.1016/j.chieco.2003.09.018

[20] Chen, L.H. (2008) Job Satisfaction among Information System (IS) Personnel. Computers in Human Behavior, 24, 105-118. http://dx.doi.org/10.1016/j.chb.2007.01.012

[21] McMurray, A.J., Scott, D. and Pace, R.W. (2004) The Relationship between Organizational Commitment and Organizational Climate in Manufacturing. Human Resource Development Quarterly, 15, 473-488. http://dx.doi.org/10.1002/hrdq.1116

[22] Department of Labor, National Skill Standards Board (2000) Built to Work: A Common Framework for Skill Standards.

[23] Rodriguez-Pose, A. and Vilalta-Bufi, M. (2005) Education, Migration and Job Satisfaction: The Regional Returns of Human Capital in the EU. Journal of Economic Geography, 5, 545-566. http://dx.doi.org/10.1093/jeg/lbh067 